\title{
Opportunity Costs of Emissions Caused by Land-Use Changes
}

\author{
S. Suyanto, Andree Ekadinata, Muhammad Sofiyuddin, Arif Rahmanullah \\ World Agroforestry Center (ICRAF Southeast Asia Program), Bogor, Indonesia \\ Email: suyanto@cgiar.org
}

Received October $16^{\text {th }}, 2013$; revised November $21^{\text {st }}$, 2013; accepted December $14^{\text {th }}, 2013$

\begin{abstract}
Copyright (C) 2014 S. Suyanto et al. This is an open access article distributed under the Creative Commons Attribution License, which permits unrestricted use, distribution, and reproduction in any medium, provided the original work is properly cited. In accordance of the Creative Commons Attribution License all Copyrights (C) 2014 are reserved for SCIRP and the owner of the intellectual property S. Suyanto et al. All Copyright (C 2014 are guarded by law and by SCIRP as a guardian.
\end{abstract}

Amid the euphoria of Reducing Emissions from Deforestation and Forest Degradation (REDD) and REDD+ discussions, the expectations of large financial gains raise the interest of all. A country, however, will only enjoy REDD benefits if the cost of REDD is lower than the benefit. The opportunity cost analysis is an effective tool for assessing the feasibility of REDD+ since the largest portion of costs associated with REDD+ and can help to identify fair compensation for those who change their land use. The opportunity cost analysis has been exercised in Tanjung Jabung Barat (Tanjabar) district-Indonesia to examine the economic-feasibility of carbon emission reduction under different type carbon price scenarios. This study reveals a sharp decline of land-use systems with high carbon-stock and low profitability is obvious. On mineral soil, low carbon-stock and high profitability (mostly oil palm) has increased rapidly, especially in the period 2000-2009. It has become the dominant land-use system. The low-to-medium carbon stock and medium profitability land-use category increased from 1990 to 2005 but declined from 2005 to 2009. The low carbon-stock and low profitability category was constant and the proportion of the area was below $15 \%$. The ex-ante analysis in predicting the potential for future emissions reduction in Tanjabar through REDD+ approaches shows that the cumulative emission of Tanjabar in 2020 is estimated at $61.91 \mathrm{Mg} \mathrm{CO}_{2-\mathrm{eq}} / \mathrm{Ha}$.Year, while the reduced emission by excluding all land use conversion below $\$ 5$ threshold is estimated at $51.71 \mathrm{Mg} \mathrm{CO}$ 2-eq $/ \mathrm{Ha}$.Year. This means that there is a potential for $16 \%$ emission reduction using \$5/ton $\mathrm{CO}_{2 \text {-eq }}$ incentive. Another important finding in this study is that if the price of carbon increases by double to $\$ 10$, the amount of reduced emission does not change much. This can use as a basis for determining the right amount of incentive for trade-off between economic profitability and climate change mitigation effort in Tanjabar using REDD+ scheme both at seller and buyer perspectives.

Keywords: Opportunity Cost; Land Use Change; Carbon Emission; REDDS

\section{Introduction}

Amid the euphoria of REDD and REDD+ discussions, the expectations of large financial gains raise the interest of all. This expectation seems reasonable as indicating by the value of REDD projects that reached USD 87 million and A/R projects USD 65 million in 2011, and where transaction volume reached significantly to 7.3 $\mathrm{MtCO}_{2 \mathrm{e}}$ for REDD projects and 7.6 $\mathrm{MtCO}_{2 \mathrm{e}}$ for A/R projects (Ecosystem Marketplace \& Bloomberg New Energy Finance, 2012). Globally, the growth of world carbon market has increased by $11 \%$ in 2011, to $\$ 176$ billion (World Bank, 2012).

REDD+ emerges as promising incentive mechanism for tropical forest protection (Huettner, 2011). Such effort requires sustained financial incentives, which go beyond positive incentives for reduced emissions but also give incentives for sustainable forest management (Mollicone et al., 2007). A country will only enjoy REDD benefits if the cost of REDD is lower than the benefit. White and Minang (2011) grouped the cost into three categories as follow (1) Opportunity cost (2) Implementation cost and (3) Transaction cost.

White and Minang (2011) argued that their analysis was focusing on opportunity costs because they will (1) be the largest portion of costs associated with REDD+; (2) provide insight into the drivers of deforestation; (3) help to understand impact; and (4) help to identify fair compensation for those who change their land use.

According to Pagiola et al. (2009), opportunity costs are usually the single most important category of costs a country would incur if it reduced its rate of forest loss to secure REDD payments. It represents the highest alternative land-use of the area under deforestation threat, including net revenue from the conversion itself (Böttcher et al., 2009).

To estimate the opportunity cost of forgone land use, we can approach at the local or micro level of return to land. By this approach, Greig-Gran (2008) revealed that opportunity cost will depend on (1) Type of land use for which the forest lands are appropriate; (2) Soil and climate conditions which in turn affect yields; (3) Scale of operation-small, medium, large; (4) Inputs and technology and (5) Distance from the market and quality of transport infrastructure. Other factors affecting the opportunity cost are the assumption of labour cost, agricultural commodities price and discount rate and time horizon used in the estimation.

Huettner et al. (2011) emphasized that the opportunity costs might change over time. It might rise because of agricultural land scarcity due to the implementation of REDD+ in combina- 
tion with future growing demand for forestry and agricultural products (Sohngen \& Beach, 2006). In this way, incentive payments need to be at a very high level to be effective against deforestation (Kindermann, 2006).

\section{Method}

The method used in this study followed the manual for estimating the opportunity cost of REDD+ published by the World Bank Institute and the REDD-Abacus software developed by the World Agroforestry Centre (Harja et al., 2011). There were four steps in the analysis (1) Clarification and description of major land uses; (2) Calculation of time-averaged carbon stock for the major land uses; (3) Calculation of the private profitability of the land uses in terms of discounted net present value; and (4) Developing the opportunity cost curve using the REDD-Abacus software. The opportunity cost curve shows the comparison of the opportunity costs of many different types of land-use change in USD per ton $\mathrm{CO}_{2 \mathrm{e}}$ and shows the quantity of potential emissions reduction per type of land-use change. The opportunity cost curve does not specify who will have to be paid how much to avoid (abate) emissions, but does provide estimates of the average and marginal opportunity costs of emission reduction (Swallow et al., 2007).

The formula to calculate the opportunity cost in USD/ton CO2e was:

$$
\frac{\mathrm{NPV}_{\text {Time2 }}-\mathrm{NPV}_{\text {Time1 }}}{3.67 \times \text { Cstock }_{\text {Time1 }}-\text { Cstock }_{\text {Time2 }}}
$$

where $\mathrm{NPV}_{\text {Time2 }}$ is net present value in at time 2 measurement, $\mathrm{NPV}_{\text {Time1 }}$ net present value in at time 1 measurement, CstockTime1 is carbon stock at time 1 measurement, and Cstock $_{\text {Time2 }}$ is carbon stock at time 2 measurement.

\section{Assumptions and Limitation}

This study employs private net present value (NPV) as the measure of return to land. Gittinger (1992) defined the NPV, the present worth of benefit less the present worth of the cost of tradable inputs and domestics factors of productions.

The study assumed that conversion cost benefit to be similar for each land-use transition type. The profitability of logging is assumed as a benefit of forest degradation (conversion from undisturbed forest to logged-over forest). This study also counted aboveground emissions while belowground/peat emissions not yet included. Forward-looking analysis used in this study is based on stationary transition probability matrix, no REDD+/policy scenario included yet. Carbon price for emission reduction was USD 5/tCO 2 .

\section{Study Site}

This study was conducted in Tanjung Jabut Barat (Tanjabar) district, Jambi province of Indonesia (Figure 1). The district has an area of $5010 \mathrm{~km}^{2}$ (BPS, 2011), where about $48 \%$ is forested lands. The district has unique historical land use as well as the existence of wide peat land area has attracted researchers to study.

\section{Result and Discussion}

\section{Trade-Off Curves of Different Land-Use Systems}

Figure 2 shows a trade-off between carbon stock and profitability of land uses on mineral soil and peatland. There are four clusters (listed below) and a couple of land uses outside the clusters which have low NPV and medium profitability: (1) High carbon-stock and low profitability; (2) Medium carbon

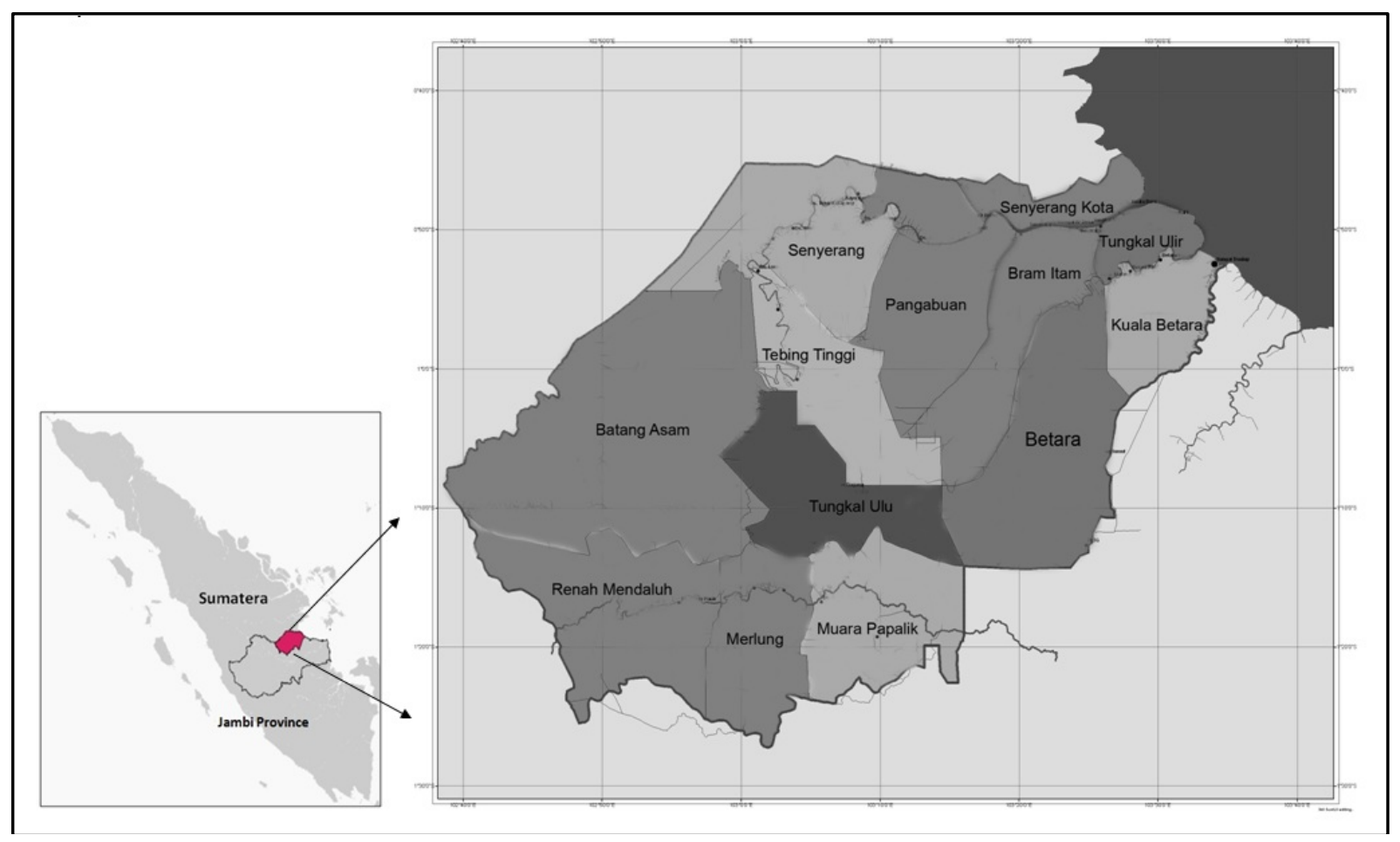

Figure 1.

Location of Tanjung Jabung Barat district, Jambi province, Sumatra, Indonesia 
stock and medium profitability; (3) Low carbon-stock and high profitability; and (4) Low carbon-stock and low profitability.

The land uses belonging to the high carbon-stock and low profitability cluster were forest and logged over forest both on mineral and peat. Agroforestry systems such as coconut-betelnut agroforests on mineral soil and coffee agroforests on peat most likely belonged to low to medium carbon stock and medium profitability. Large-scale and smallholder oil palm on both mineral and peat were categorised as low carbon-stock and high profitability.

Figures 3 and 4 show the changes of land-use configuration in Tanjabar in terms of carbon stock and economic profitability. Both on mineral and peat, a sharp decline of land-use systems with high carbon-stock and low profitability was obvious. On mineral soil, low carbon-stock and high profitability (mostly oil palm) has increased rapidly, especially in the period 2000-2009. It has become the dominant land-use system. The low-to-medium carbon stock and medium profitability land-use category increased from 1990 to 2005 but declined from 2005 to 2009. The low carbon-stock, low profitability category was constant and the proportion of the area was below 15\%. Table 1 shows

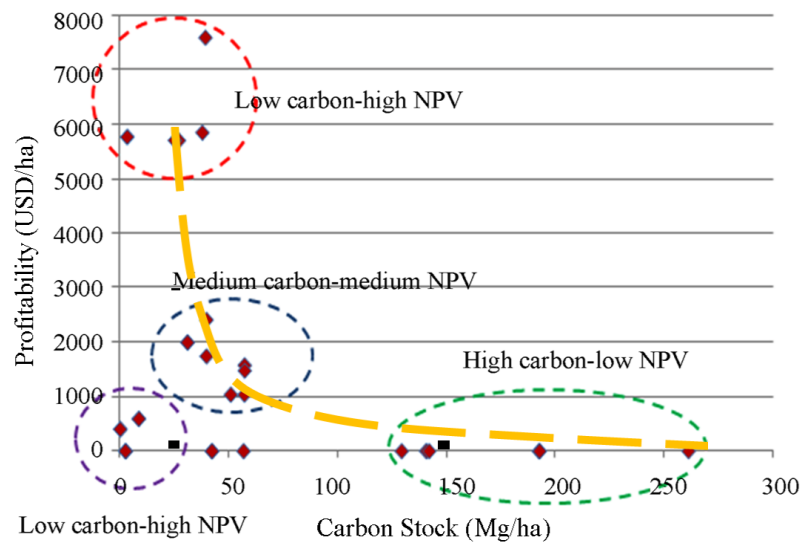

Figure 2.

Clusters of land-use systems based on carbon stock and net present value.
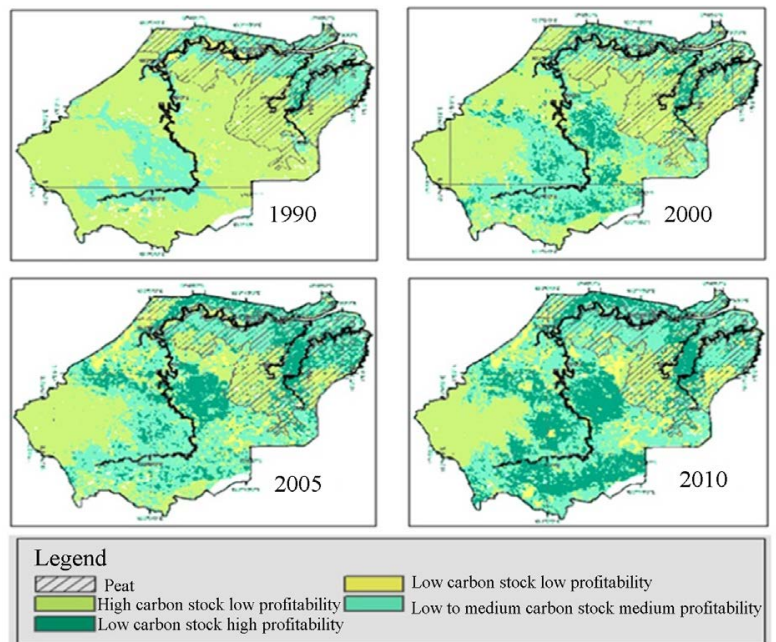

Figure 3.

Changes of land-use configuration in Tanjabar in terms of carbon stock and economic profitability.
Table 1.

Carbon stock and net present value of land use systems in Tanjabar.

\begin{tabular}{|c|c|c|c|c|c|}
\hline \multirow{2}{*}{ No } & \multirow{2}{*}{ Land-use system } & \multicolumn{2}{|c|}{$\begin{array}{c}\text { Carbon stock } \\
\text { (ton/ha) }\end{array}$} & \multicolumn{2}{|c|}{$\begin{array}{l}\text { Private NPV } \\
\text { (USD/ha) }\end{array}$} \\
\hline & & Mineral & Peat & Mineral & Peat \\
\hline 1 & Undisturbed forest & 262 & - & - & - \\
\hline 2 & $\begin{array}{l}\text { Logged over forest: } \\
\text { high density }\end{array}$ & 193 & - & - & - \\
\hline 3 & $\begin{array}{l}\text { Logged over forest: } \\
\text { low density }\end{array}$ & 130 & - & - & - \\
\hline 4 & $\begin{array}{c}\text { Undisturbed swamp } \\
\text { forest }\end{array}$ & 193 & 193 & - & - \\
\hline 5 & $\begin{array}{c}\text { Logged over swamp } \\
\text { forest }\end{array}$ & 141 & 141 & - & - \\
\hline 6 & $\begin{array}{l}\text { Undisturbed } \\
\text { mangrove }\end{array}$ & 143 & - & - & - \\
\hline 7 & $\begin{array}{l}\text { Logged over } \\
\text { mangrove }\end{array}$ & 58 & - & - & - \\
\hline 8 & Rubber agroforest & 58 & 58 & 1580 & 1481 \\
\hline 9 & $\begin{array}{c}\text { Coffee based } \\
\text { agroforest }\end{array}$ & 28 & 26 & 5722 & 5722 \\
\hline 11 & Acacia plantation & 58 & 52 & 1040 & 1040 \\
\hline 12 & Rubber monoculture & 41 & 41 & 2417 & 1747 \\
\hline 13 & Oil palm & 40 & 39 & 7615 & 5866 \\
\hline 14 & $\begin{array}{l}\text { Coconut betel nut } \\
\text { agro forest }\end{array}$ & 32 & 32 & 2002 & 2002 \\
\hline 15 & Shrub & 43 & 43 & - & - \\
\hline 16 & Grass & 3 & 3 & - & - \\
\hline 17 & Other crops & 10 & 10 & 595 & 595 \\
\hline 18 & Rice field & 1 & 1 & 404 & 404 \\
\hline 19 & Cleared land & 3 & 3 & - & - \\
\hline 20 & Settlement & 4 & 4 & 5787 & 5787 \\
\hline
\end{tabular}

Note: ${ }^{1}$ Rahayu et al. (2011); ${ }^{2}$ Sofiyuddin et al. (2012).

the carbon stock and NVP that use for opportunity cost analysis.

On peat, low-to-medium carbon stock and medium profitability land use increased sharply in the period 2000-2009. This category was mostly agroforests and was the dominant land use on peat soil. The low carbon-stock, high profitability category also increased but the proportion of the area was still lower than the low-to-medium carbon stock, medium profitability category.

\section{Retrospective Analysis of Opportunity Costs for Emission Reduction}

Opportunity cost curves for Tanjabar in the periods 19902000-2005-2009 are shown in Figures 5-7.

By examining the threshold of US dollars as the potential price of 1 ton $\mathrm{CO}_{2}$ we can see how much emissions could have been compensated or abated. During 1990-2000, emissions below the threshold of USD5 were 4.49 ton $\mathrm{CO}_{2 \mathrm{e}} /$ ha/year and increased to 10.28 ton $\mathrm{CO}_{2 \mathrm{e}}$ /ha/year for 2000-2005 (Figures 5 and 6). The increase of eligible emissions demonstrates the higher emissions from conversion to lower NPV land uses. 


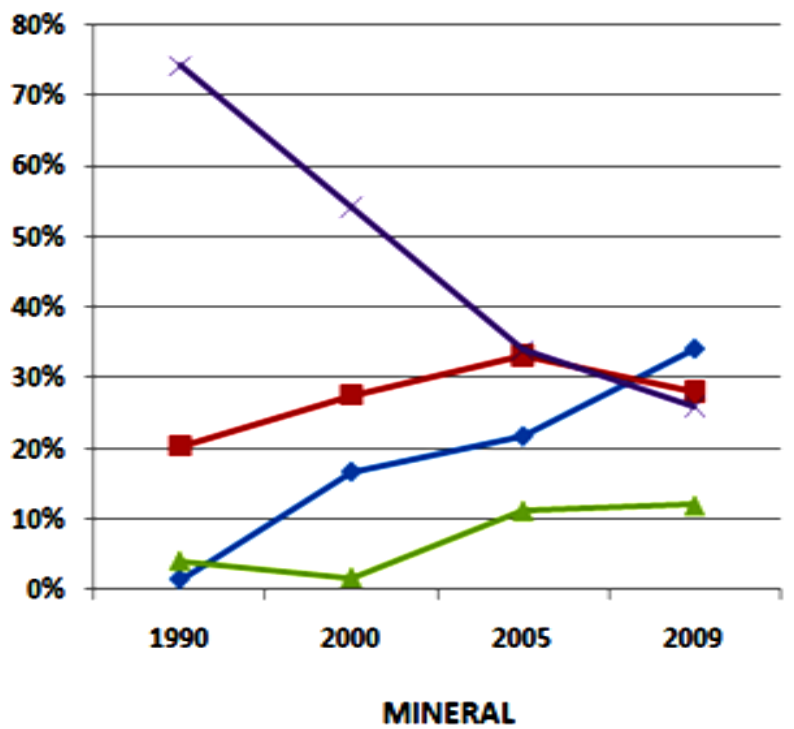

$\sim$ Low carbon stock high profitability -Low carbon stock low profitability

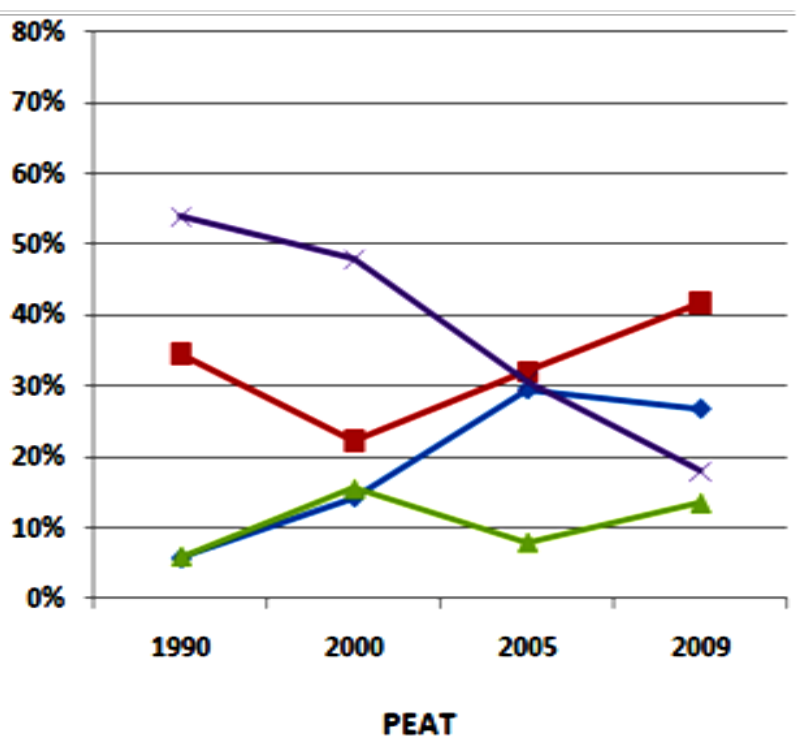

Low to medium carbon stock medium profitability High carbon stock low profitability

Figure 4.

Land-use system changes in Tanjabar.

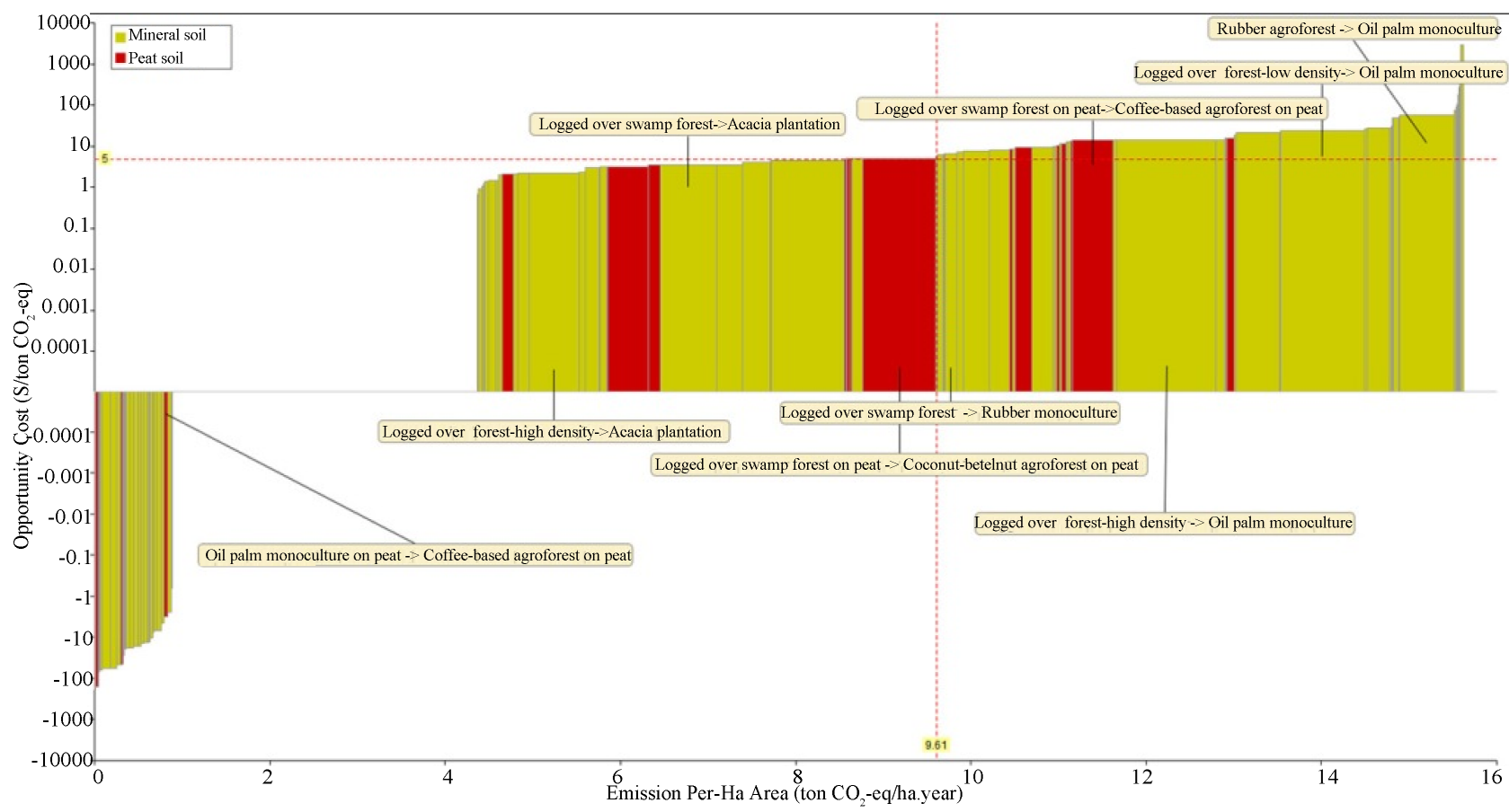

Figure 5.

Opportunity cost curve for Tanjabar, 1990-2000.

During 2005-2009, the amount of emissions below the USD5 threshold decreased slightly to 9.53 ton $\mathrm{CO}_{2 \mathrm{e}}$ /ha/year (Figure 7).

From the total annual emissions, the proportion of emissions that could have been avoided in Tanjabar increased over the period of analysis. For $1990-2000$, the proportion was $42 \%$, for 2000-2005 it was 58\% and for 2005-2009 the proportion was
64\%. These increasing figures demonstrate that emissions reduction efforts could have been successful. A higher proportion of emissions could have been avoided with a similar price of carbon. This also shows potential for future emissions reduction in Tanjabar through REDD+ and Reducing Emmission from All Land Used (REALU) approaches. 


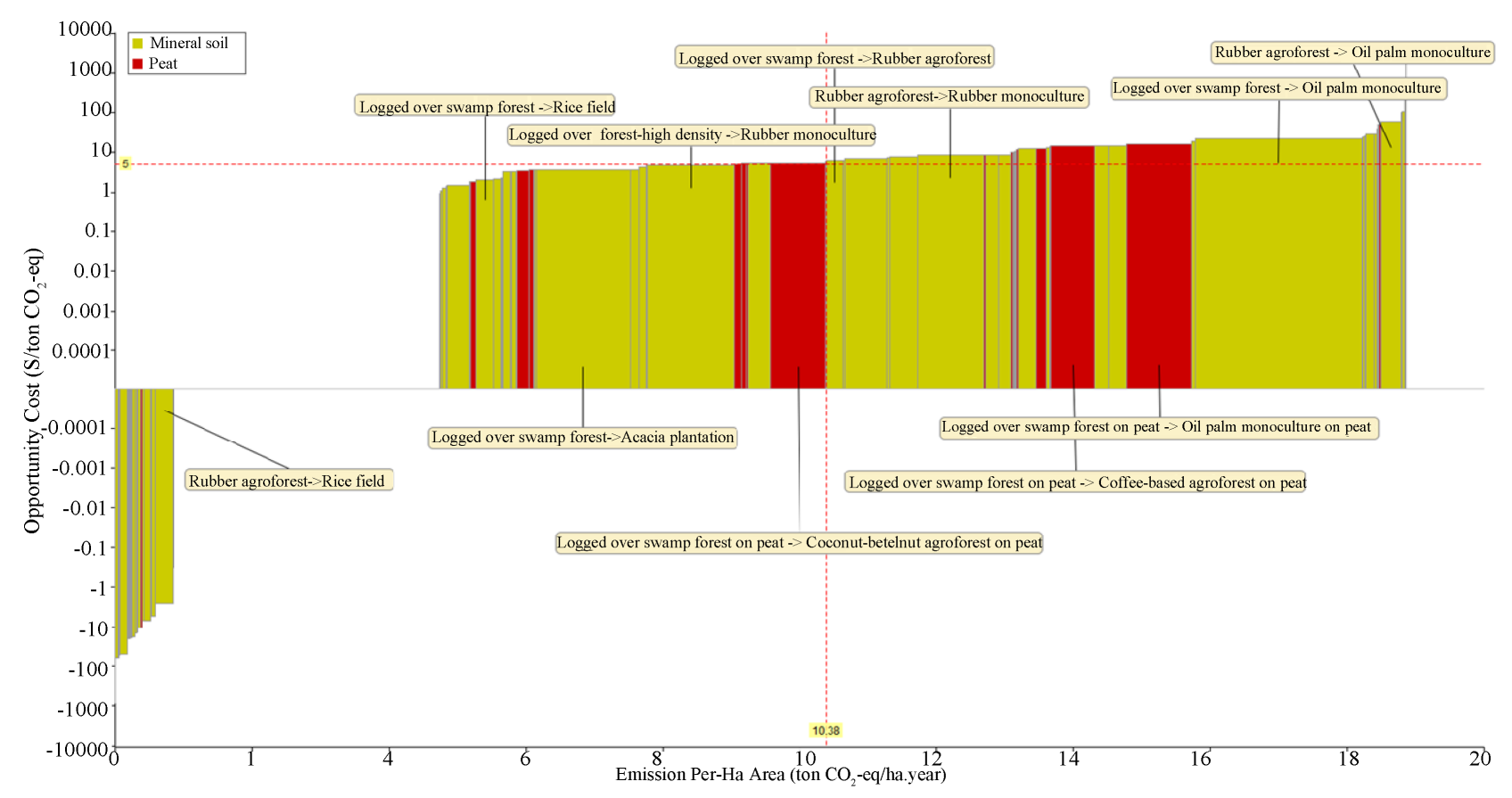

Figure 6.

Opportunity cost curve for Tanjabar, 2000-2005.

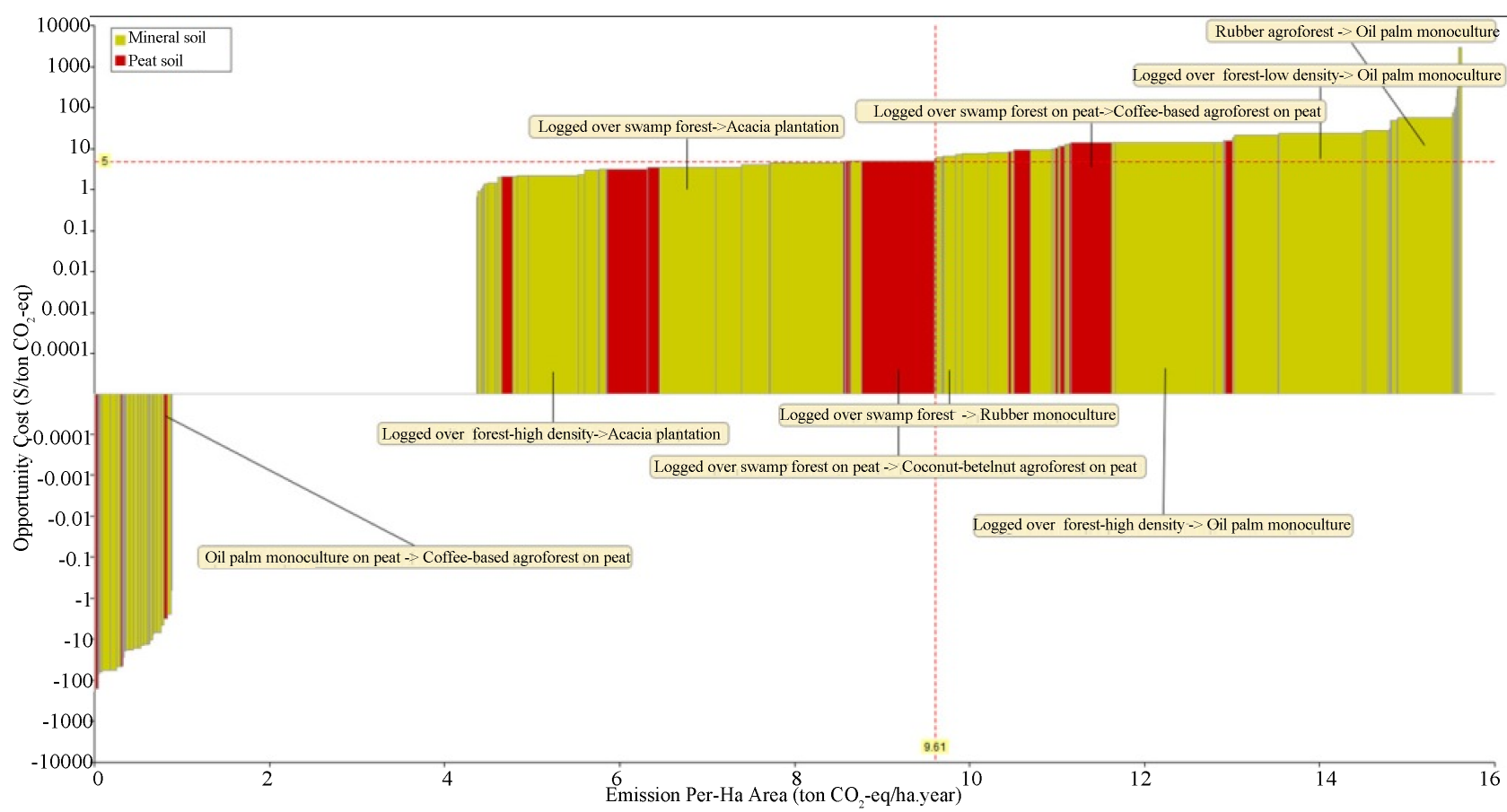

Figure 7.

Opportunity cost curve for Tanjabar, 2005-2009.

Figure 8 showed potential emission reduction of Tanjabar in 2020, assuming that all emission with opportunity cost below $\$ 5$ can be avoided.

Cumulative emission of Tanjabar in 2020 is estimated at $61.91 \mathrm{Mg} \mathrm{CO} \mathrm{CO}_{2 \text {-eq }} / \mathrm{Ha}$.Year, while the reduced emission by excluding all land use conversion below \$5 threshold is estimated at $51.71 \mathrm{Mg} \mathrm{CO}_{2 \text {-eq }} / \mathrm{Ha}$.Year. This means that there is a potential for $16 \%$ emission reduction using $\$ 5 /$ ton $\mathrm{CO}_{2 \text {-eq }}$ incentive. The $\$ 5$ threshold is quite significant in the case of Tanjabar. Even by increasing the threshold to $\$ 10$, the amount of reduced emission does not change much. This can be used as a basis for determining the right amount of incentive for tradeoff between economic profitability and climate change mitigation effort in Tanjabar using REDD+/REALU scheme. 


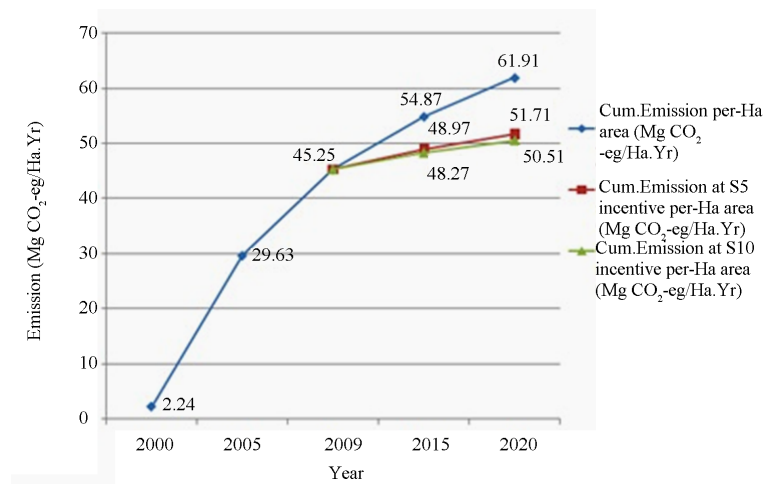

Figure 8.

Potential Emission reduction at $\$ 5$ and $\$ 10$ threshold.

\section{Conclusion}

The ex-ante analysis in predicting the potential for future emission reduction through REDD+/REALU approaches shows that the cumulative emission of Tanjabar in 2020 is estimated at $61.91 \mathrm{Mg} \mathrm{CO} \mathrm{CO}_{2-\mathrm{eq}} / \mathrm{Ha}$.Year. Based on retrospective analysis, there is a potential for $16 \%$ emission reduction using $\$ 5 /$ ton $\mathrm{CO}_{2 \text {-eq }}$ incentive. However, if the the threshold is increased to $\$ 10$, the amount of reduced emission does not change much.

Large proportion of emission in Tanjabar cannot be compensated through incentive mechanism since it will result in large opportunity cost. This is a good example of many areas in Indonesia where development activity, although it produces large amount of emission, also has significant amount of profitability that is important for local development. Insignificant amount of potentially avoided future emission through incentive mechanism indicates opportunities to derive policy intervention toward low emission development strategy by conserving high carbon stock areas and focused development on land with high carbon-high profitability through participative approach such as land use planning.

\section{Acknowledgements}

This publication is supported by the NORAD-funded project, "Reducing Emissions from All Land Uses (REALU) and CGIAR Research Program on Forests, Trees and AgroforestryLandscape Management (CRP-6.3). The authors would like to thank the communities of Tanjung Jabung Barat district for their generous hospitality and their patient participation in the surveys and authors thank Robert Finlayson, ICRAF Regional Communications Specialist for English editing.

\section{REFERENCES}

Böttcher, H., Eisbrenner, K., Fritz, S., Kindermann, G., Kraxner, F., McCallum, I., \& Obersteiner, M. (2009). An assessment of monitoring requirements and costs of "Reduced Emissions from Deforestation and Degradation”. Carbon Balance and Management, 4, 7. http://www.cbmjournal.com/content/4/1/7/
BPS (2011). Tanjung Jabung Barat Dalam Angka 2010. Jambi: Badan Pusat Statistik Kabupaten Tanjung Jabung Barat.

Gittinger, J. P. (1982). Economic analysis of agricultural project (2nd ed.). Baltimore: John Hopkins University Press.

Grieg-Gran, M. (2008). The cost of avoiding deforestation. London: International Institute for Environment and Development (IIED). http://pubs.iied.org/pdfs/G02290.pdf

Huettner, M. (2011). Risks and opportunities of REDD+ implementation for environmental integrity and socio-economic compatibility. Environmental Science, 15, 4-12.

http://www.sciencedirect.com/science/article/pii/S146290111100152 $\underline{3}$

Harja, D., Dewi, S., Van Noordwijk, M., Ekadinata, A., \& Rahmanulloh, A. (2011). REDD Abacus SP. User Manual and Software. http://www.worldagroforestry.org/sea/projects/allreddi/softwares

Kindermann, G., Obersteiner, M., Sohngen, B., Sathaye, J., Andrasko, K., Rametsteiner, E., Schlamadinger, B., Wunder, S., \& Beach, R. (2008). Global cost estimates of reducing carbon emissions through avoided deforestation. Proceedings of the National Academy of Sciences of the United States of America, 105, 10302-10307. http://dx.doi.org/10.1073/pnas.0710616105

Kindermann, G., Obersteiner, M., Rametsteiner, E., \& McCallum, I. (2006). Predicting the deforestation-trend under different carbonprices. Carbon Balance and Management, 17.

Mollicone, D., Freibauer, A., Schulze, E. D., Braatz, S., Grassi, G., \& Federici, S. (2006). Elements for the expected mechanisms on "reduced emissions from deforestation and degradation (REDD)" under UNFCCC. Environmental Research Letters, 2, 7.

Pagiola, S., \& Bosquet, B. (2009). Estimating the costs of REDD+ at country level. Version 2.2, Washington, DC: Forest Carbon Partnership Facility, World Bank.

Peters-Stanley, M., \& Hamilton, K. (2012). Developing Dimension: State of the voluntary carbon market 2012. Washington, DC: The Ecosystem Marketplace and Bloomberg New Energy Finance.

Sofiyuddin, M., Rahmanulloh, A., \& Suyanto, S. (2012). Assessment of profitability of land use systems in Tanjung Jabung Barat District, Jambi Province, Indonesia. Open Journal of Forestry, 2, 252-256. http://dx.doi.org/10.4236/ojf.2012.24031

Sohngen, B., \& Beach, R.H. (2006). Avoided deforestation as a greenhouse gas mitigation tool: Economic issues for consideration (p. 40). Columbus: The Ohio State University.

Rahayu, S., Khasanah, N., \& Asmawan, T. (2011). Above and belowground carbon stock. In A. Widayati, S. Suyanto, \& M. van Noordwijk (Eds.), Towards reduced emissions in a high-stake district REALU project design for Tanjung Jabung Barat (Tanjabar), Jambi, Indonesia (pp. 59-73). Project Report, Bogor: World Agroforestry Centre-ICRAF Southeast Asia.

Swallow, B., Van Noordwijk, M., Dewi, S., Murdiyarso, D., White, D., Gockowski, J., Hyman, G., Budidarsono, S., Robiglio, V., Meadu, V., Ekadinata, A., Agus, F., Hairiah, K., Mbile, P. N., Sonwa, D. J., \& Weise, S. (2007). Opportunities for avoided deforestation with sustainable benefits. An interim report by the ASB partnership for the tropical forest margins. Nairobi: ASB Partnership for the Tropical Forest Margins.

White, D., \& Minang, P. (2011). Estimating the opportunity costs of REDD+. A training manual. Washington, DC: World Bank Institute.

World Bank (2012). State and trends of carbon market report 2012. http://web.worldbank.org/WBSITE/EXTERNAL/TOPICS/ENVIRO NMENT/EXTCARBONFINANCE/0, contentMDK:23206428 men uPK:5575595 pagePK:64168445 piPK:64168309 theSitePK:41258 53 isCURL:Y,00.html 